\title{
Rationalism, Complexity Science and Curriculum: A Cautionary Tale
}

ANNE M. PHELAN

University of British Columbia

The following essay was first presented as a raconteur's closing response to speakers at the 2004 Complexity Science and Educational Research Conference in Chaffey's Locks, Ontario, Canada, September 30-October 3. 
... something not lost or hidden

but just not found yet...

- Atwood (1998)

\section{Rational Seductions: An Autobiographical Note}

I grew up impatient with my mother's stories of family events, virtues and relationships. Her stories were as poetical as they were literal; insistent in their actuality as much as their possibility; they embodied feeling and fiction and disrupted our daily routines. My mother's stories were imaginative spaces, allegories of what I might become. A person whom she hoped would be educated and who could, as a result, live life with dignity, integrity and pride.

I took my mother's implicit invitation to escape, nay, transcend the concrete particulars of my life and of her stories. At five years of age, I abandoned her fictions and made my way to school. There I was encouraged to reject her mythos and embrace the logos of objective truth, knowledge that could be relied on in all cases and places. The promise of mastery of a predetermined and well-defined body of knowledge, reasoned impeccably and cleansed of feeling or body, was reassuring in the extreme. My teachers seemed to know little of their students' lives. Not to be found out; hiding amidst their abstractions, to be someone other, I felt at home at last. Curriculum was a ritual cleansing from the burdens of a very ordinary life.

However, my curriculum experiences were not without risk. That ghostly territory where human experience is stored remained obscure. As many of my peers, I became a product of academic socialization and differentiation, a keen example of an alliance between able students, Plato and educational institutions. The reward: entry into third-level education.

At college I continued my pursuit of objective truth in the company of philosophy professors. In Oxford tutorial style, Professor Thorn lectured four of us on logic; at the age of eighteen, Aristotelian syllogisms didn't make a lot of common sense to me but I persevered. Professor Smith lectured two hundred of us on history of philosophy; we moved deftly from Plato to Isocrates to Aristotle, from Kant to Hegel to Heidegger in a frenzied dance; all were important, none seemed distinctive enough for the eager examination student. In Professor Firth's class we moved from one foundational narrative to another, Descartes' enlightenment, Rousseau's individual potential, Habermas's liberation. Interestingly, students never spoke during those lectures and tutorials. I learned to "suffer" through the texts of someone else's certainties while sacrificing my mother's stories and my own lived experience over and over again. Safe from the particulars of the practical realm, the realm of ill-structured problems-a child's death, an 
adolescent's resistance and a student's questions-my professors and I could ignore the difficulties of human affairs and the ultimate fragility of those grand narratives. The reward: a teaching degree.

By now I had accepted the concepts, language and vague significance of rationalism. I had learned to speak a different language to my mother; the language of the Father. Reason and I had become entangled in some Freudian liaison. I never thought to wonder where this procession of educated men was leading me (Woolf, 2001). I left those parts of my lived experience that did not fit inside the dominant molds of rationalism to pour and splash over the edges of what was acceptable and allowable. The reward: a teaching position.

Having returned to the school I had once attended as a child, the rational seduction continued as instrumentalism became the raison d'être of practice. Curriculum came packaged with its own guarantees. Curriculum came packaged with its own guarantees of nationhood, economic progress, religion or university admissions. Mandated programs of study, basal curricula, correct teaching strategies and standardized testing would lead to the guaranteed outcomes. Those outcomes, of course, had already been decided on in advance of any child or teacher entering the classroom. Not surprisingly, the good students did well. The average students did averagely. The poor students did poorly (Smith, 1988). Graduate school became a flight from curriculum as guarantee. Ironically, Marxism constituted the next seduction!

Marx's drama of the forward march of human productive capacities via class conflict culminating in a proletarian revolution was the kind of overarching, self-legitimating philosophy I was after. At that time, neomarxism was prominent in curriculum studies, introduced to North America by Brazilian educator Paulo Freire and advanced in the works of various writers such Giroux, McLaren, Macedo, Apple and others. The impossibility of hegemony, saturated consciousness and hidden curriculum posited against powerful practices of consciousness raising, socially critical thought and a utopian vision of a just society were compelling in the extreme. Reason would be my ally as I identified contradictions in the social and educational worlds, knowledge of which would subsequently lead to justice, truth and human emancipation. The hidden, the null, the official curriculum took on a spectral evil in light of the latest grand narrative. The reward: a teaching position at a university.

\section{Rationalism and Complexity Science as Language Games}

Jean Francois Lyotard (1984) likens "language games" (Wittgenstein, 2001) to the game of chess, defined by a set of rules which in turn determine the properties of each piece, the appropriate way to move them. 
[The] rules do not carry within themselves their own legitimation, but are the object of a contract, explicit or not, between players... [I]f there are no rules, there is no game.... [E]very utterance should be thought of as a "move" in a game (Lyotard, 1984 , p. 10).

As a language game, rationalism comes with its own rules of engagementobjectivity, certainty, universality, instrumentality and predictability. However, the game is played within various "forms of life" (Lebensformen) and the latter provide the background and context against and in which the game plays out its sense and reference (Schrag, 1997, p. 32). While the contributions of rationalism may have been profound in different fields, I have tried to demonstrate its implications and entanglements in education. From my perspective, it has contributed to the full poverty of curriculum and schooling: a flight from the particulars of experience; the search for valuefree knowledge; a factory model of schooling and curriculum with efficiency and ends as central; and an emphasis on technical and procedurally resolvable problems rather than on normative questions of human living, a curriculum of unfounded guarantees (Beyer, 1988).

It is against this backdrop of disenchantment that I come to complexity science and consider its potential for curriculum and schooling. Having listened to presentations and engaged in conversations with participants throughout the conference, my sense is that I am not alone in my critique of rationalism. We are weary of curricula immunized from the human condition and devoid of story, attachment and meaning. I have witnessed our "ruthless intentionality" (Dewey, 1933) as we pursue what we hope will be a more worthwhile language game. Like all language games, complexity science has a performative aspect to it. Not unlike participants in a wedding ceremony, in each presentation we utter tentatively "I do", sometimes with limited knowledge of the implications of our commitment! The gesture is powerful, however, as it ushers in a promise to try, to try on, to try out a different way of being and acting in the world. Our search, perhaps, is for an ontology of difference, one that invites a responsiveness and responsibility to the Other, a form which Varela calls ethical coping (1999). I honour that search for it presupposes that complexity science may bring something into presence that has so far been unfound in the educational realm. And yet....

\section{Three Cautionary Notes on Language, Power and Universalism}

My fear is that we are constructing a redemptive tale and that in complexity science we see not simply another language game but a shining new set of guarantees. And so, I am led to wonder what this new language is up to? We have to ask, with Lyotard (1984): what one must do in order to be heard, 
what one must listen to in order to speak, and what role one must play to be the object of this language game. What happens to the educator who begins to play this game, who utters phrases such as "diversity", "complexity", "system", "collective", "self-organizing", or "co-emergence"? What is this particular language game up to? What does it insist upon saying? What are the things that cannot be said? Does complexity science present itself as guarantee, promise, question, prescription, order or story? What is the structure of its address? What are the social bonds that it creates among its players: children and their teachers, academics and their pre-service teachers, policy makers and their publics? Is it a language game that invites difference? What type of knowledge is at stake in complexity science? Is its paradigmatic home in science or in narrative? Is it paradoxically both at once, a new move within established games? Or is it a new game in and of itself?

It is too early in this game to answer these questions. In fact, it may be dangerous to interrogate too soon before the game has time to take shape amongst the players. There is a sense in which we are still in the romantic phase of our relationship with complexity science (Whitehead, 1967). I am repeatedly struck, for example, at the array of characters that we draw into this language game: Dewey, Whitehead, Buddha, Maturana, Varela, Rorty, Aristotle, Gadamer and Plato. Is this an example of "neighbour interactions" (Davis, Sumara \& Kieren, 1996) wherein different ideas / agents bump up against one another to provide a rich understanding of learning? Is this yet another procession of educated men (Woolf, 2001)? Or, is this the Mad Hatter's tea party come to life?! At some point, we will need to enter a stage of refinement and precision (Whitehead, 1967) during which we examine carefully the contribution, or otherwise, that each of these thinkers can make to this particular language game.

However, perhaps a few cautions are worth articulating at this stage if only to further the conversation about complexity science and curriculum, not to interrupt it.

The first caution relates to language. Our difficulty is not in embracing new ideas but in ridding ourselves of the old. Rationalism is ever present in our language. Osberg and Biesta (2003) have been effective in their challenge to participants to rethink the representational assumptions we make: that the world is "present" and meaning precedes signification. These authors challenge us to rethink this metaphysics of presence and to conceive of signification as the site of our meaning making. Language, in other words, constitutes reality; it does not simply describe it. Throughout the preceding paragraphs, I have spoken of complexity science as an "it" implying some reality outside of our construal of it and yet I am trying to make the claim that " $i t$ " is a language game, constituted within an ongoing, dynamic interaction between players of that game! Throughout the conference presenters 
have also fallen into this trap. We heard much of classrooms, schools and organizations as entities that seemed to exist outside of language. We spoke of complexity science as a "lens" on that reality. On other occasions, complexity science became a "tool" that can lead us towards better practice in schools. The instrumental logic of rationalism persisted as we abstracted relations of teaching and learning into mechanistic and dehumanized metaphors of "nodes" and "networks". Might complexity science tug us toward the hermeneutic and invite an interpretive and linguistic turn in our thought and practice? If so, then language and its relationship to "reality" must continue to be a strong presence in our conversations.

The second caution relates to the matter of power. It is the paradoxes of complexity science that entice and trouble me at the same. Consider the notion of internal diversity as the source of a system's intelligence. The system, however, tends towards coherence. How is that coherence arrived at? Are some of those diverse ideas eliminated, contained or resolved? Why, therefore, might particular ideas hold sway in a classroom discussion? Why might some ideas never appear on the table? Why might particular forms of learning unfold? How do the "emerging" ideas serve the interests of some and not others? The notion of "collective authorizing" of ideas deserves further inquiry in this regard: Who is included in the "collective"? Whose voices are heard or silenced? There may be a danger in this language game that we forget the dynamic of power/knowledge at play in the classroom (Foucault, 1972). At the subterranean level there seems to be a kind of naturalism at play. As such the language of the social theory seemed largely absent during the conference. There was no mention of feminism, no question about social justice and no apparent concern with inequity. Each language game is inevitably limited; it has that which it recognizes as true and that which it does not even see. Recognizing that the limits of our language are the limits of our world may lead us into fruitful conversations with unsuspected others (Wittgenstein, 2001). It may also mean that we must be intellectually humble in our claims for complexity science as it pertains to curriculum as a political practice.

The final caution brings us back to the notion of guarantee and the problem of universalism. There seems to be a wicked irony at play when, in our efforts to delineate a pedagogy informed by complexity science, that we begin to identify five conditions, four qualities, and three principles for complex practice. The consequence is that we try to transcend the particularities of practice, immunizing teaching and learning yet again from the density of human experience. At our peril we return to a place where practice is seen as "merely an expression of embarrassment at the deplorable but soon to be overcome condition of incomplete theory" (Bubner, 1981, p. 204). We have a long history of disembedding knowledge from the immediacy and 
idiosyncrasy of particular teaching situations and from the experience of teachers (Dunne \& Pendlebury, 2002). Through such decontextualizing, we suppose that what is essential in knowledge and skill can be encapsulated in explicit, generalizable formulae. The temptations of rationalism persist and we are in danger of forgetting that the whole of relevant reality is more complex than any one educational theory suggests or implies.

\section{A Promise of Wise Practice}

Notwithstanding these cautions, I continue to be intrigued by the promise (without guarantees) of complexity science. This can be an immensely hopeful language game if we can nurture two rules of engagement that were at times evident during this conference: the play of thought and the ethical claim of our attachments. These rules, paradoxically, relate to the notion of practical wisdom-the a-rational dimension of Aristotle's thinking (Nussbaum, 1990).

First, consider the opening address of this year's Complexity Science and Educational Research Conference, given by Elizabeth Morley, Principal of the Institute of Child Study Laboratory School at the Institute of Child Study at the Ontario Institute for Studies in Education at the University of Toronto. By inviting Elizabeth's narrative about practices of teaching and learning at the laboratory school, we began our conversations at this conference with the particular: a particular context, a particular group of children, and a particular way of educating. In this manner, we were provided a referent and so many times throughout the conference we returned to that context, moving back and forth between its particulars and the more theoretical abstractions of complexity science. The particular is prioritized and it does not appear in the form of example or instance of a larger theory but as the initial ground of inquiry. The concrete situation has the power to change our general theoretical understanding. The experience of a particular child can reinforce or invite us to question our current understandings. This is the play of thought between our understanding of a particular child's questions and our knowledge of "expanding the space of the possible" (Davis, 2004); between identifying the ways in which children explore the physical world and our more general, theoretical understanding of "emergence". In this manner, our study of complexity science is driven by an attitude of inquiry, and as such is potentially transformational, an endowment of meaning with significance rather than a manipulation of predetermined meaning.

Secondly, we need to consider the ethical claim that complexity science makes on us. We need to continue to question the normative power of this language game. How does it help us become aware of and raise questions about "what is good or bad, what is worth doing or what not, what has 
meaning and importance for us and what is trivial and secondary" in curriculum practice (Taylor, 1989, p. 28)? By inviting each other to consider our commitments and attachments in light of the grounds that support them and the further conclusions to which they lead, we will be better able to ethically justify our position to those who may not play the same language game.

\section{In Closing}

In "Women and Madness", Phyllis Chesler notes that women are motherless children in patriarchal society (1972). By this she means that women have neither power nor wealth to hand on to their daughters; the most they can do is teach their daughters the tricks of surviving in the patriarchy by pleasing, and attaching themselves to powerful or economically viable men; marriage her only real profession (Rich, 1979). Adrienne Rich (1979) draws the parallel with Jane Eyre who as a poor and genteel woman in nineteenth century England had one possible source of independence if she did not marry: the profession of governess. I suggest that Jane found in Rochester, what we found in rationalism. Like mad women in the attics that are our schools, we like Jane, rummage about motherless, in search of Atwood's unfound thing. Is complexity science that unfound thing? Might it the language of the mother?

\section{References}

Atwood, M. A Place: Fragments. In the Circle Game. Toronto, ON: House of Anansi Press Limited, 1998.

Beyer, L. Knowing and Acting: Inquiry, Ideology and Educational Studies. London, UK: Falmer Press, 1988

Boland, E. Code. Manchester, UK: Carcanet Press, 2001

Bubner, R. Modern German Philosophy. Cambridge: Cambridge University Press, 1981.

Chesler, P. Women and Madness. Garden City, NY: Doubleday Publishers, 1972.

Davis, A. B. "Teaching with difference: Dissipating structure." Paper presented at the Complexity Science and Educational Research Conference, Chaffey's Locks, Ontario, Canada, September 30-October 3, 2004

Davis, A. B., D. J. Sumara, and T. E. Kieren,. "Cognition, Co-emergence, Curriculum." Journal of Curriculum Studies 28, no. 2 (1996): 151-169.

Dewey, J. Art As Experience. New York: Minton, Balch \& Company. 1934.

Doll, W. E. "Modes of thought." In Proceedings of the 2003 Complexity Science and Educational Research Conference, October 16-18, edited by B. Davis, 1-10, Edmonton, Canada, 2003, http:// www.complexityandeducation.ualberta.ca/Documents/CSERProceedingsPDFsPPTs/CSER Doll.pdf (accessed 2004 Nov 25)

Dunne, J. Back to the Rough Ground: Practical Judgment and the Lure of Technique. London: Cambridge University Press, 1997. 
Dunne, J. and S, Pendlebury. Practical Reason. In The Blackwell Guide to the Philosophy of Education, edited by U. Blake, P. Swayer, R. Smith, and P. Standish, 194-211. Oxford: Blackwell Publishers, 2002.

Foucault, M. The Archaeology of Knowledge. London: Tavistock, 1972.

Lyotard, J. F. The Postmodern Condition: A Report on Knowledge. Translated by Geoff Bennington and Brian Massumi. Minneapolis: University of Minnesota Press, 1984.

Nussbaum, M. The Fragility of Goodness: Essays on Philosophy and Literature. Cambridge: Cambridge University Press, 1990.

Osberg, D. \& Biesta, G. “Complexity, Representation and the Epistemology of Schooling." In Proceedings of the 2003 Complexity Science and Educational Research Conference, October 16-18. edited by B. Davis, Edmonton, Canada, 2003. http: / / www.complexityandeducation.ualberta.ca/Documents / CSERProceedingsPDFsPPTs/CSER Osberg Biesta.pdf (accessed 2004 Nov 25).

Rich, A. On Lies, Secrets and Silences: Selected Prose, 1966-1978. New York, NY: W. W. Norton \& Company, 1979.

Smith, D. "Experimental Eidetics as a Way of Entering Curriculum Language from the Ground Up." In Contemporary Curriculum Discourses, edited by William Pinar, Scottsdale, AR: Gorsuch Scarisbrick, Publishers, 1988.

Schon, D. A. The Reflective Practitioner: How Professionals Think in Action. New York: Basic Books, 1983.

Schrag, C. O. The Self After Postmodernity. New Haven: Yale University Press, 1997.

Taylor, C. Sources of the Self: The Making of the Modern Identity. Cambridge, MA: Harvard University Press, 1989.

Varela, F. Ethical Know-how. Cambridge: Cambridge University Press, 1999.

Whitehead, A. N. The Aims of Education. 1929. Reprint, New York: The Free Press, 1967. Wittgenstein, L. Philosophical Investigations. Oxford, UK: Blackwell, 2001.

Woolf, V. A Room of One's Own. Peterborough, ON: Broadview Press, 2001.

\section{About the Author}

Anne M. Phelan is an Associate Professor in the Department of Curriculum Studies in the Faculty of Education at the University of British Columbia. Her research and teaching interests include curriculum theory and pre-service teacher education. Her current work explores the discourses of conflict in the professional education of teachers, nurses, social workers and physicians. 